Economics Development Analysis Journal 5(4)(2016)

\title{
Dampak Realokasi Anggaran Belanja Subsidi BBM untuk Pembangunan Infrastruktur terhadap Perekonomian Indonesia
}

\author{
Muhammad Anas $^{1 凶}$, Wahyu Widodo ${ }^{2}$, FX Sugiyanto ${ }^{3}$ \\ ${ }^{1,2}$ Magister Ilmu Ekonomi dan Studi Pembangunan Universitas Diponegoro \\ ${ }^{3}$ Gedung C Fakultas Ekonomika dan Bisnis Universitas Diponegoro
}

\begin{abstract}
Info Artikel
Abstrak

Sejarah Artikel:

Diterima September

2016

Disetujui Oktober 2016

Dipublikasikan

November 2016

Keywords:

fuel subsidy, infrastructure,

$S A M$, economic growth,

household income, household

poverty

Kondisi dan daya saing infrastruktur Indonesia belum memadai akibat belanja infrastruktur yang terhambat karena membengkaknya anggaran subsidi BBM. Pada akhir tahun 2014, pemerintah mereformasi anggaran belanja dengan memangkas anggaran subsidi BBM dan meningkatkan anggaran pembangunan infrastruktur. Penelitian ini bertujuan menganalisis dampak realokasi anggaran belanja subsidi BBM untuk pembangunan infrastruktur terhadap perekonomian Indonesia. Dengan menggunakan data yang bersumber dari BPS dan Susenas, penelitian ini menerapkan aplikasi Sistem Neraca Sosial Ekonomi (SNSE) sebagai alat analisis untuk melihat seberapa besar dampak kebijakan bagi pertumbuhan ekonomi dan pendapatan rumah tangga. Hasil simulasi menunjukkan bahwa realokasi anggaran subsidi BBM untuk pembangunan infrastruktur sosial (seperti pendidikan dan kesehatan) berpengaruh lebih besar terhadap perekonomian Indonesia dibandingkan infrastruktur fisik (seperti jalan dan jembatan). Meski pertubuhan ekonomi yang diperoleh melalui hasil simulasi belum mencapai target pembangunan, namun dalam jangka panjang pembangunan infrastruktur diharapkan mampu mengakselerasi pertumbuhan ekonomi.
\end{abstract}

\begin{abstract}
Indonesia's infrastructure has been inadequate and not competitive due to the lack of infrastructure spending because of the consistently increasing budget for fuel subsidy. Therefore, at the end of 2014, Government of Indonesia (GoI) reformed their budgeting policy by diverting fuel subsidy's budget to develop infrastructure. The purpose of this study was to analyze the impact of diverting Indonesia's budgeting policy from fuel subsidy to infrastructure on its economy. Using data from Statistics Indonesia and National Survey of Social and Economy, this study applied Social Accounting Matrix (SAM) as the analytical tool to quantify the magnitude of the impact from the policy on Indonesia's economic growth and household income. Simulation results indicated that developing social infrastructure (such as education and health) had a bigger impact on Indonesia's economy than developing physical infrastructure (such as roads and bridges). Although the economic growth resulted from the simulation policy could not meet Indonesia's target, infrastructure spending is expected to accelerate growth in the long run.
\end{abstract}

(C) 2016 Universitas Negeri Semarang

\begin{tabular}{lr}
\hline Alamat korespondensi: & ISSN 2252-6765 \\
J1.Prof.H.Soedarto, S.H.Tembalang, Tembalang, Kota Semarang, & \\
Jawa Tengah 50275 & \\
E-mail: m.anas.assegaf@gmail.com &
\end{tabular}




\section{PENDAHULUAN}

Infrastruktur merupakan aspek penting bagi perekonomian suatu negara atau daerah. Menurut Todaro \& Smith (2012), infrastruktur berperan sebagai penggerak aktivitas ekonomi. Buruknya infrastruktur seperti jalan, rel, saluran air, serta pelayanan publik seperti pendidikan dan kesehatan menjadi salah satu penyebab tertinggalnya suatu daerah. Buruknya infrastruktur juga menjadi salah satu penyebab rendahnya pertumbuhan ekonomi di Afrika (lihat Easterly \& Levine, 1997). Sementara itu, Schwab (2015) dalam laporan The Global Competitiveness Report menyatakan bahwa infrastruktur dapat mengurangi kesenjangan antar wilayah, menurunkan biaya transaksi, serta mempercepat pertumbuhan ekonomi dan mengentaskan kemiskinan.

Mengingat pentingnya peran infrastruktur, pemerintah hendaknya menjadikan infrastruktur sebagai salah satu prioritas pembangunan. Namun pada kenyataannya, proporsi anggaran infrastruktur terhadap PDB masih rendah. Berdasarkan laporan Bank Dunia (lihat Diop, 2014), proporsi anggaran infrastruktur hanya sebesar 2,5 persen dari PDB. Salah satu indikasi rendahnya belanja infrastruktur adalah membengkaknya belanja BBM. Berdasarkan publikasi Kementerian Keuangan (Kemenkeu), dalam kurun waktu 2005 hingga 2014, belanja subsidi BBM meningkat lebih dari dua kali lipat dari 104,78 triliun Rupiah menjadi 239,99 triliun Rupiah. Kecenderungan belanja subsidi BBM yang terus meningkat dinilai menjadi penyebab sempitnya ruang fiskal pemerintah.

Realita yang terjadi di Indonesia justru menjadi perdebatan apakah subsidi BBM sudah tepat sasaran, karena banyak muncul berita bahwa sebagian besar BBM bersubsidi dinikmati oleh masyarakat golongan menengah ke atas. Berdasarkan laporan Bank Dunia (lihat Diop, 2014), sebesar 84 persen BBM bersubsidi di Indonesia dinikmati oleh masyarakat golongan ekonomi menengah ke atas, dan hanya 16 persen yang dinikmati masyarakat golongan ekonomi menengah ke bawah. Dalam dokumen APBN-P 2015 pun Kemenkeu juga menyatakan bahwa kebijakan subsidi BBM masih perlu desain dan pengawasan yang lebih baik agar distribusinya lebih tepat sasaran.

Tabel 1. Nilai dan Peringkat Daya Saing Infrastruktur Indonesia Tahun 2014

\begin{tabular}{lcc}
\hline \multicolumn{1}{c}{ Kategori } & $\begin{array}{c}\text { Nilai (Skala } \\
\mathbf{1 - 7 )}\end{array}$ & $\begin{array}{c}\text { Peringkat (dari 144 } \\
\text { Negara) }\end{array}$ \\
\hline Quality of Roads & 3.9 & 72 \\
Quality of Railroad Infrastructure & 3.7 & 41 \\
Quality of Port Infrastructure & 4.0 & 77 \\
Quality of Air Transport Infrastructure & 4.5 & 64 \\
Qualitiy of Electricity Supply & 4.3 & 84 \\
Quality of Overall Infrastructure & 4.2 & 72 \\
\hline
\end{tabular}

Sumber: Schwab (2015), The Global Competitiveness Report (GCR)

*) indeks/skala yang semakin medekati nilai 7 menunjukkan kondisi infrastruktur yang semakin baik

Berdasarkan Tabel 1, kondisi peringkat 41, yaitu pada infrastruktur rel kereta infrastruktur Indonesia masih belum memadai. api. Kondisi tersebut merupakan imbas dari Dari masing-masing indikator, dengan skala rendahnya anggaran pembangunan infrastruktur satu hingga tujuh, nilai yang diperoleh akibat membengkaknya beban belanja subsidi Indonesia bahkan tidak ada yang mencapai BBM yang bahkan hingga saat ini distribusinya lima. Peringkat terbaik Indonesia pun hanya masih tidak merata. 
Melonjaknya belanja subsidi BBM mengakibatkan rendahnya belanja infrastruktur sehingga kondisi infrastruktur di Indonesia belum memadai. Hal tersebut berujung pada rendahnya pertumbuhan ekonomi. Berdasarkan data Bank Dunia, pertumbuhan ekonomi Indonesia mengalami penurunan dari 6,22 persen pada tahun 2010 menjadi 5,02 persen pada tahun 2015. Atas dasar tersebut, pemerintah pada November 2014 menetapkan kebijakan realokasi anggaran belanja subsidi BBM untuk pembangunan infrastruktur. Pada RAPBN 2016, Belanja infrastruktur dipangkas dari 239,99 triliun Rupiah menjadi hanya 70,96 triliun Rupiah (turun 169,03 triliun Rupiah). Realokasi anggaran subsidi BBM untuk pembangunan sektor produktif (salah satunya infrastruktur) diharapkan mampu meningkatkan performa perekonomian Indonesia.

Penelitian ini bertujuan untuk menganalisis dampak pembangunan infrastruktur melalui dana realokasi dari subsidi BBM terhadap perekonomian Indonesia. Untuk mengakomodasi tujuan tersebut, penelitian ini menggunakan analisis Sistem Neraca Sosial Ekonomi (SNSE). Pada penelitian ini juga akan dilakukan analisis lebih lanjut dengan basis hasil simulasi SNSE, yaitu membandingkan jumlah rumah tangga miskin antara sebelum dengan setelah dilakukannya simulasi kebijakan. Dengan demikian, dapat diketahui seberapa besar kebijakan realokasi anggaran subsidi BBM untuk membangun infrastruktur berperan dalam mengurangi kemiskinan.

Penelitian yang membahas pengurangan anggaran subsidi dan peningkatan anggaran infrastruktur telah banyak dilakukan. Penelitian yang dilakukan oleh Burniaux (2014) menunjukkan bahwa pengurangan subsidi BBM di sejumlah negara-negara non-OECD dapat mengurangi gas rumah kaca dunia (GRK) sebesar $10 \%$ pada tahun 2050. Aschauer (1989) menggunakan model regresi OLS dan memperoleh hasil bahwa infrastruktur inti (jalan, bandara, saluran air, transportasi publik, dan instalasi listrik dan gas) berpengaruh positif terhadap Total Factor Productivity (TFP) di Amerika. Dengan model yang sama, Ford \&
Poret (1991) menemukan bahwa rendahnya belanja infrastruktur menjadi penyebab turunnya TFP. Sementara itu, Palei (2015) membuktikan bahwa kualitas infrastruktur berpengaruh positif terhadap daya saing Rusia.

Model analisis dampak juga banyak digunakan pada penelitian terdahulu. Raihan (2011) menggunakan analisis Sistem Neraca Sosial Ekonomi (SNSE) dan memperoleh hasil bahwa belanja infrastruktur dapat meningkatkan output sektoral dan pendapatan rumah tangga. Sementara itu, Bonakdarpour, Brodesky, \& Campbell (2014) menggunakan model inputoutput (I-O) dan memperoleh hasil bahwa peningkatan belanja infrastruktur transportasi akan meningkatkan GPD dan kesempatan kerja.

Terkait pengurangan belanja subsidi, penelitian Widodo et al. (2012) dan Fathurrahman (2014) menggunakan model SNSE dan sama-sama memperoleh hasil bahwa output dan pendapatan rumah tangga akan turun, namun realokasi anggaran untuk belanja pada sektor lain akan kembali mengingkatkan perekonomian. Penelitian Ogarenko \& Hubacek (2013) dan Cooke et al. (2014) menggunakan model I-O dan membuktikan bahwa pemangkasan anggaran subsidi akan menurunkan pendapatan rumah tangga, namun program transfer dapat kembali meningkatkan pendapatan rumah tangga.

Perbedaan krusial penelitian ini dibandingkan dengan penelitian-penelitian sebelumnya adalah pada penelitian ini akan dilakukan analisis lanjutan dengan basis analisis yang berasal dari hasil simulasi SNSE. Analisis lanjutan yang dilakukan penghitungan kemiskinan rumah tangga. Penghitungan kemiskinan rumah tangga dilakukan untuk membandingkan tingkat kemiskinan rumah tangga antara sebelum dan setelah dilakukannya simulasi kebijakan.

\section{METODE PENELITIAN}

Penelitian ini menggunakan SNSE untuk menganalisis dampak simulasi kebijakan realokasi anggaran subsidi BBM untuk pembangunan infrastruktur terhadap 
perekonomian Indonesia. Untuk mengetahui seberapa besar dampak tersebut, dilakukanlah perkalian nilai gejolak (shock) dengan matriks pengganda $\left(\mathrm{M}_{\mathrm{a}}\right)$.

$$
y=M_{a} x
$$

Pada Persamaan (1), y menunjukkan neraca endogen yang terdiri dari faktor produksi, institusi, dan sektor produksi. Nilai y akan berubah sebesar $M_{a}$ apabila terjadi perubahan satu unit pada neraca eksogen (x) yang merupakan nilai shock.

Simulasi pada penelitian ini adalah mengurangi anggaran belanja subsidi BBM dan meningkatkan anggaran infrastruktur. Dalam merumuskan shock penurunan belanja subsidi BBM, penelitian ini menggunakan pendekatan permintaan, yaitu melalui persentase perubahan belanja BBM pada sektor yang BBM-nya disubsidi, kemudian mengalikannya dengan besarnya nilai penurunan anggaran subsidi BBM $\left(\Delta G_{\text {BBM }}\right)$. Nilai $\Delta G_{\text {Bвм }}$ adalah sebesar 169,03 triliun Rupiah seperti telah dijelaskan pada Pendahuluan.

Tidak terdapat publikasi atau informasi detail mengenai sektor mana saja yang BBMnya disubsidi, dan pada publikasi Kementerian Energi dan Sumber Daya Mineral (KESDM) hanya terdapat data konsumsi BBM sektor transportasi, industri, PLN (listrik), komersial, rumah tangga, dan lainnya. Untuk mengatasi kendala tersebut, penelitian ini hanya akan menjadikan sektor transportasi dan listrik sebagai sasaran, karena BBM sektor industri bukan merupakan BBM bersubsidi.

Asumsi pada penelitian ini adalah $\Delta \mathrm{G}_{\mathrm{BBM}}$ seluruhnya digunakan untuk membangun infrastruktur. Infrastruktur pada penelitian ini akan dikategorikan menjadi infrastruktur fisik (sektor 41 pada SNSE) dan infrastruktur sosial (sektor 49 pada SNSE) ${ }^{1}$. Pada penelitian ini akan dilakukan beberapa skenario, yaitu (1) $\Delta \mathrm{G}_{\text {BBM }}$ dialokasikan sepenuhnya untuk sektor 41

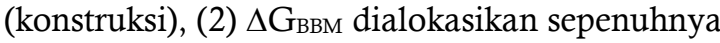

untuk sektor 49 (pendidikan dan kesehatan), (3) $\Delta \mathrm{G}_{\text {BBM }}$ dialokasikan untuk sektor 41 dan 49 dengan porsi masing-masing 50 persen, (4) $\Delta \mathrm{G}_{\mathrm{BBM}}$ dialokasikan untuk sektor 41 sebesar 78,67 persen dan untuk sektor 49 sebesar 21,33. Hal tersebut berdasarkan publikasi Sekretariat Kabinet (Setkab, 2015).

\section{Penghitungan Kemiskinan Rumah Tangga}

Tujuan dari analisis ini adalah mengetahui seberapa besar dampak simulasi kebijakan dalam menurunkan tingkat kemiskinan rumah tangga. Adapun tingkat kemiskinan rumah tangga pada penelitian ini diukur menggunakan indeks Foster-GreerThorbecke (FGT) seperti yang dilakukan oleh Parra \& Wodon (2010):

$$
P_{\alpha}=\frac{1}{n} \sum_{i=1}^{q}\left(\frac{z-y_{i}}{z}\right)^{\alpha}
$$

$\mathrm{P}$ menunjukkan ukuran kemiskinan, $\mathrm{n}$ adalah jumlah rumah tangga, $\mathrm{q}$ adalah jumlah rumah tangga miskin, $\mathrm{z}$ adalah Garis Kemiskinan, dan y adalah rata-rata pengeluaran per bulan rumah tangga miskin. Jika nilai $\alpha=0$ maka $\mathrm{P}_{0}$ menunjukkan Head Count Index (HCI) atau persentase rumah tangga miskin. Jika $\alpha=1$ maka $\mathrm{P}_{1}$ menunjukkan Indeks Kedalaman Kemiskinan (Poverty Gap Index / PGI) yaitu kesenjangan rata-rata konsumsi rumah tangga miskin terhadap Garis Kemiskinan. Jika $\alpha=2$ maka $\mathrm{P}_{2}$ menunjukkan Indeks Keparahan Kemiskinan (Poverty Severity Index / PSI) yaitu kesenjangan konsumsi antar rumah tangga miskin. Untuk dapat memperoleh jumlah rumah tangga miskin, maka terlebih dahulu harus tersedia data jumlah rumah tangga untuk tiap kategori pada SNSE dan konsumsi tiap rumah tangga. Data tersebut diperoleh dengan mengolah hasil kuesioner Survei Sosial Ekonomi Nasional (Susenas) 2013.

Simulasi kebijakan yang dilakukan akan menghasilkan peningkatan pendapatan rumah tangga. Untuk mengetahui seberapa besar 
penurunan tingkat kemiskinan rumah tangga, maka persentase peningkatan pendapatan rumah tangga akan ditambahkan pada konsumsi rumah tangga miskin dari tiap kategori. Dengan demikian, dapat diketahui berapa banyak rumah tangga yang konsumsinya kemudian melewati Garis Kemiskinan. Langkah selanjutnya adalah menghitung nilai $\mathrm{P}_{\alpha}$ setelah shock masing-masing skenario.

\section{HASIL DAN PEMBAHASAN}

\section{Dampak Kebijakan terhadap Output}

Simulasi kebijakan penurunan anggaran subsidi BBM mengakibatkan output turun sebesar 1,37 persen, dengan sektor transportasi mengalami penurunan terbesar (Lihat Lampiran 1). Pembangunan infrastruktur masing-masing skenario akan meningkatkan output sebesar 5,50 persen; 5,82 persen; 5,66 persen; dan 5,57 persen. Sektor konstruksi serta pendidikan dan kesehatan mengalami peningkatan output terbesar ${ }^{2}$. Peningkatan output lebih besar terjadi jika infrastruktur lebih difokuskan pada pendidikan dan kesehatan. Pendidikan dan kesehatan merupakan faktor yang dapat meningkatkan efisiensi tenaga kerja, sehingga pembangunan fasilitas pendidikan dan kesehatan dapat mempercepat pertumbuhan ekonomi

Meski jika diakumulasikan pertumbuhan output yang dihasilkan dari masing masing skenario belum mencapai target pertumbuhan ekonomi pada RAPBN sebesar 5,5 persen, namun pembangunan infrastruktur yang menghasilkan pertumbuhan output yang tinggi diharapkan dapar mengakselerasi pertumbuhan ekonomi dalam jangka panjang.

\section{Dampak Kebijakan terhadap Pendapatan Rumah Tangga}

Simulasi kebijakan penurunan anggaran subsidi BBM mengakibatkan pendapatan rumah tangga turun sebesar 1,40 persen, dengan kategori rumah tangga golongan atas di kota mengalami penurunan terbesar. Pembangunan infrastruktur masing-masing skenario akan meningkatkan pendapatan rumah tangga sebesar 5,16 persen; 7,39 persen; 6,28 persen; dan 5,64 persen. Rumah tangga golongan atas di kota menikmati peningkatan pendapatan terbesar dari tiap skenario ${ }^{3}$. Distribusi pendapatan rumah tangga setelah shock cenderung tidak mengalami perubahan. Rumah tangga golongan atas di kota msih menjadi penerima pendapatan tebesar. Meski demikian, kesenjangan proporsi peningkatan pendapatan tiap kategori rumah tangga cenderung kecil, yang mengindikasikan bahwa pendapatan tiap kategori rumah tangga meningkat secara proporsional.

Pembangunan infrastruktur skenario 2 meningkatkan pendapatan rumah tangga dengan peningkatan terbesar, begitu juga dengan penurunan kemiskinan. Secara keseluruhan, simulasi kebijakan akan menurunkan persentase rumah tangga miskin untuk masing-masing skenario sebesar 0,53 persen; 1,20 persen; 0,86 persen; dan 0,66 persen ${ }^{4}$. Penurunan $\mathrm{P}_{0}, \mathrm{P}_{1}$, dan $\mathrm{P}_{2}$ terbesar terjadi pada rumah tangga golongan rendah dan rumah tangga pertanian ${ }^{5}$. Meski bila dilihat berdasarkan persentase penurunan rumah tangga miskin terbilang kecil, namun secara absolut cukup banyak penurunan jumlah rumah tangga miskin. Secara keseluruhan, penurunan jumlah rumah tangga miskin dari masingmasing skenario adalah 6094 rumah tangga, 7928 rumah tangga, 7010 rumah tangga, dan 6482 rumah tangga. Meski simulasi kebijakan dapat menurunkan kemiskinan tangga dengan jumlah yang cukup besar, namun masih banyak pula rumah tangga miskin yang belum banyak terbantu. Pembangunan infrastruktur yang dapat 
memperbaiki aksesibilitas masyarakat dan mengurangi kesenjangan antar daerah diharapkan dapat membantu menurunkan tingkat kemiskinan rumah tangga dengan jumlah yang lebih besar dalam jangka panjang.

\section{SIMPULAN}

Subsidi BBM yang terus membebani APBN selama tahun 2005 hingga 2014 justru lebih banyak dinikmati kalangan mampu. Selain itu, beban anggaran subsidi BBM yang membengkak mengakibatkan terhambatnya belanja sektor prioritas, salah satunya infrastruktur. Pada November 2014, pemerintah melakukan reformasi anggaran dengan memangkas anggaran subsidi BBM dan mengalihkannya untuk pembangunan infrastruktur.

Berdasarkan hasil penelitian, pembangunan infrastruktur pendidikan dan kesehatan memberikan pengaruh yang lebih besar terhadap output dan pendapatan rumah tangga. Simulasi kebijakan dapat meningkatkan output sektor produksi meski belum mencapai target pertumbuhan ekonomi 5,5 persen. Namun, pertumbuhan output yang tinggi melalui shock pembangunan infrastruktur mengindikasikan bahwa pembangunan infrastruktur dapat mengakselerasi pertumbuhan ekonomi dalam jangka panjang.

Dari sisi pendapatan rumah tangga, simulasi kebijakan cenderung tidak menyebabkan perubahan distribusi pendapatan. Namun, pendapatan rumah tangga meningkat secara proporsional. Simulasi yang dilakukan juga dapat menurunkan tingkat kemiskinan dengan jumlah yang cukup besar, yaitu rata-rata 6800 rumah tangga tiap skenarionya. Meski demikian, masih banyak rumah tangga yang masih berstatus miskin, terutama rumah tangga pertanian.

Berdasarkan hasil penelitian, meski penurunan anggaran subsidi BBM memberikan gejolak pada perekonomian, namun pembangunan infrastruktur dapat kembali memperbaiki perekonomian. Oleh karena itu, peemrintah perlu menyertakan kebijakan penurunan anggaran BBM dengan pembangunan sektor produktif, salah satunya infrastruktur. Pembanginan infrastruktur yang difokuskan pada pembangunan dan perbaikan fasilitas pendidikan dan kesehatan menghasilkan peningkatan output dan pendapatan rumah tangga terbesar. Pemerintah perlu menjadikan sektor pendidikan dan kesehatan sebagai salah satu alternatif prioritas pembangunan. Pemerintah juga dapat merealokasikan anggaran subsidi BBM untuk pembangunan infrastruktur pertanian seperti perbaikan saluran irigasi. Hal tersebut bertujuan agar kinerja sektor pertanian dan pendapatan petani meningkat, serta menurunkan tingkat kemiskinan rumah tangga petani dengan porsi yang lebih besar, mengingat rumah tangga petani merupakan golongan rumah tangga dengan tingkat kemiskinan terbesar.

Bagi penelitian sejenis selanjutnya, perlu adanya kajian lebih lanjut mengenai pengklasifikasian infrastruktur pada sektor produksi SNSE agar dapat merumuskan skenario kebijakan dengan lebih akurat dan memperoleh hasil yang lebih baik.

\section{DAFTAR PUSTAKA}

Aschauer, David Alan. 1989. "Is Public Expenditure Productive?" Journal of Monetary Economics 23(September 1988): 177-200.

Bonakdarpour, Mohsen, Robert Brodesky, and Karen A. Campbell. 2014. "Transportation Infrastructure Investment: Macroeconomic and Industry Contribution of the Federal Highway and Mass Transit Program." In Transportation Construction Coalition, Philadelphia.

Burniaux, Jean-Marc and Jean Chateau. 2014. Greenhouse gases mitigation potential and economic efficiency of phasing-out fossil fuel subsidies. International Economics, 140, pp.7188.

Cooke, Edgar F A et al. 2014. "Estimating the Impact on Poverty of Ghana's Fuel Subsidy Reform and A Mitigating Response." Partnership for Economic Policy (PEP) Working Paper II.

Diop, Ndiame. 2014. Why Is Reducing Energy Subsidies a Prudent, Fair, and Transformative Policy for Indonesia? Jakarta.

Easterly, William, and Ross Levine. 1997. "Africa's 
Growth Tragedy: Policies and Ethnic Divisions." The Quarterly Journal of Economics 112(4): 1203-50.

Fathurrahman, Fahman. 2014. "Simulating Indonesian Fuel Subsidy Reform: A Social Accounting Matrix (SAM) Analysis." Middle East Technical University.

Ford, Robert, and Pierre Poret. 1991. "Infrastructure and Private-Sector Productivity." Economic Studies 17(Autumn): 63-89.

Lin, Boqiang and Xiaoling Ouyang. 2014. A revisit of fossil-fuel subsidies in China: Challenges and opportunities for energy price reform. Energy Conversion and Management, 82, pp.124-134.

Ogarenko, Iuliia, and Klaus Hubacek. 2013. "Eliminating Indirect Energy Subsidies in Ukraine: Estimation of Environmental and Socioeconomic Effects Using Input - Output Modeling."

Palei, Tatyana. 2015. "Assessing the Impact of Infrastructure on Economic Growth and Global Competitiveness." Procedia Economics and Finance 23(October 2014): 168-75. http://linkinghub.elsevier.com/retrieve/pii/S 2212567115003226.

Parra, Juan Carlos, and Quentin Wodon. 2010. SimSIP SAM: A Tool for the Analysis of Input-Output Tables and Social Accounting Matrices. Washington DC.
Raihan, Selim. 2011. Infrastructure and Growth and Poverty in Bangladesh. Manila. http://mpra.ub.uni-muenchen.de/37882/.

Samli, A. Coskun. 2011. Economic Infrastructuring: The Key to Achieve Economic Growth, Productivity, and Quality of Life. New York: Springer Science+Business Media.

Schwab, Klaus. 2015. The Global Competitiveness Report 2014-2015: Full Data Edition. Geneva.

Setkab. 2015. "Berterima Kasih Kepada Rakyat, Presiden Jokowi Jelaskan Alokasi Pengalihan Anggaran Subsidi BBM." Berita. http://setkab.go.id/berterima-kasih-kepadarakyat-presiden-jokowi-jelaskan-alokasipengalihan-anggaran-subsidi-bbm/ (December 21, 2015).

Siddig, Khalid. 2014. Impacts of removing fuel import subsidies in Nigeria on poverty. Energy Policy, 69, pp. $165-178$

Todaro, Michael P., and Stephen C. Smith. 2012. Economic Development. 11th ed. Boston: Addison-Weasley.

Widodo, Tri, Gumilang Aryo Sahadewo, Sekar Utami Setiastuti, and Maftuchatul Chaerriyah. 2012. "Impact of Fuel Subsidy Removal on Government Spending." In Energy Market Integration in East Asia: Theories, Electricity Sector and Subsidies, Jakarta: ERIA, 173-206. 
Lampiran 1. Klasifikasi SNSE Indonesia 53x53

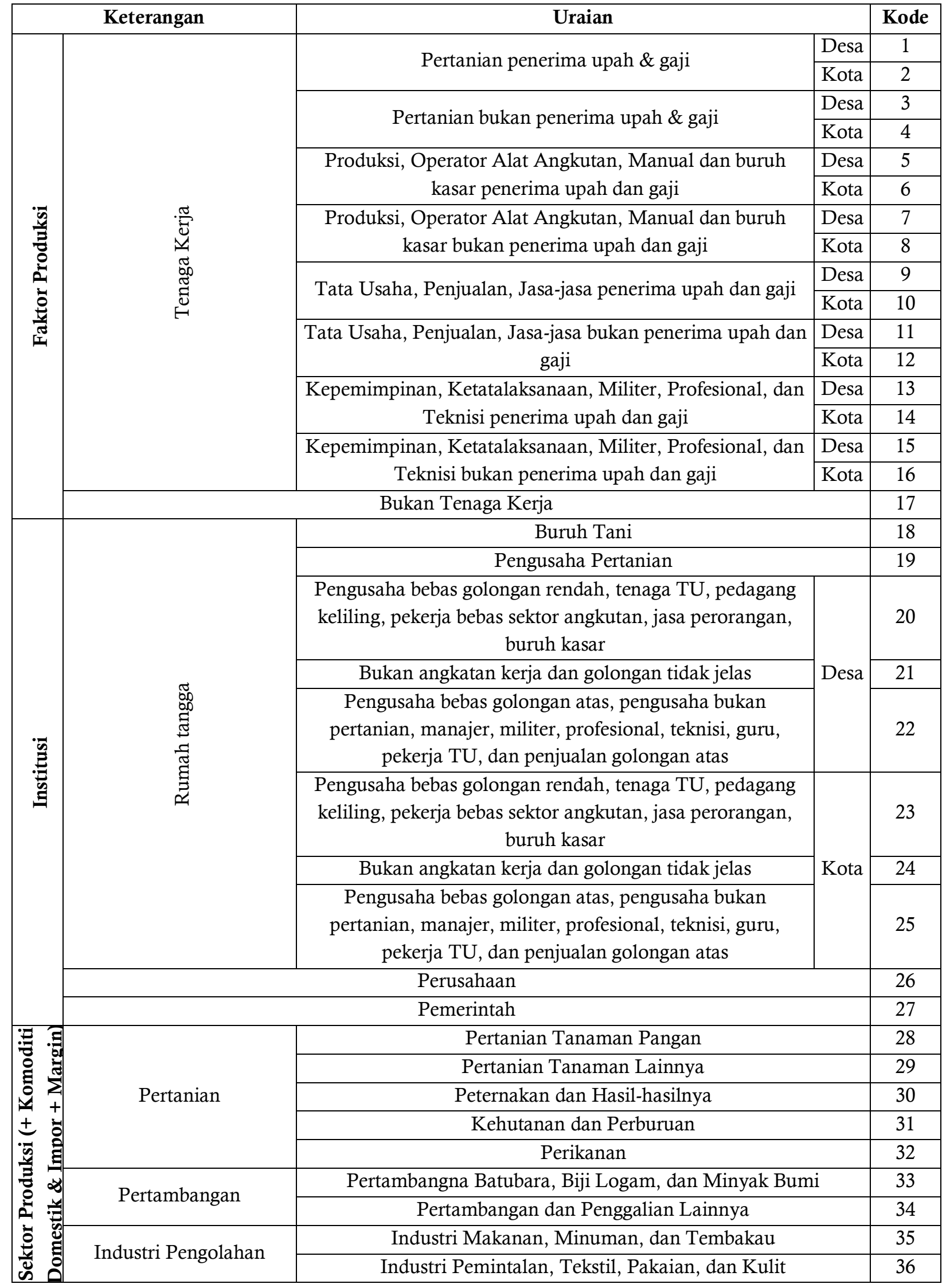




\begin{tabular}{|c|c|c|}
\hline & Industri Kayu \& Barang dari Kayu & 37 \\
\hline & $\begin{array}{c}\text { Industri Kertas, Percetakan, Alat Angkutan, dan Barang dari } \\
\text { Logam }\end{array}$ & 38 \\
\hline & Industri Kimia, Pupuk, Hasil dari Tanah Liat, Semen & 39 \\
\hline & Listrik, Gas dan Air Minum & 40 \\
\hline & Konstruksi & 41 \\
\hline \multirow{4}{*}{$\begin{array}{l}\text { Perdagangan, Restoran \& } \\
\text { Perhotelan, Pengangkutan } \\
\text { \& Komunikasi }\end{array}$} & Perdagangan besar dan eceran, jasa penunjang angkutan & 42 \\
\hline & Restoran & 43 \\
\hline & Perhotelan & 44 \\
\hline & Angkutan & 45 \\
\hline \multirow{4}{*}{$\begin{array}{c}\text { Lembaga Keuangan, Real } \\
\text { Estate, Pemerintah, Jasa } \\
\text { Sosial dan Kebudayaan, } \\
\text { Jasa Hiburan, Jasa } \\
\text { Perseorangan dan RT }\end{array}$} & Bank dan asuransi & 47 \\
\hline & Real estate dan jasa perusahaan & 48 \\
\hline & $\begin{array}{l}\text { Pemerintahan dan pertahanan, pendidikan, kesehatan, jasalain, } \\
\text { film, dan rekreasi }\end{array}$ & 49 \\
\hline & Jasa perorangan, rumah tangga, dan jasa lainnya & 50 \\
\hline \multicolumn{3}{|l|}{ Lampiran 1 (lanjutan) } \\
\hline \multicolumn{2}{|c|}{ Neraca Kapital } & 99 \\
\hline \multicolumn{2}{|c|}{ Pajak tidak langsung } & 100 \\
\hline \multicolumn{2}{|r|}{ Subsidi } & 101 \\
\hline \multicolumn{2}{|r|}{ Luar Negeri } & 102 \\
\hline
\end{tabular}

Sumber: BPS

Catatan: SNSE yang digunakan adalah SNSE 2008 102x102 yang sudah diagregasi sesuai kebutuhan penelitian. 


\section{Lampiran 2}

Tabel 1. Dampak Injeksi Realokasi Anggaran Belanja Subsidi BBM untuk Pembangunan Infrastruktur (Skenario 1) terhadap Output Sektor Produksi di Indonesia ${ }^{6}$

\begin{tabular}{|c|c|c|c|c|}
\hline \multirow{2}{*}{ Kode SNSE } & Output Awal & Output Setelah Shock & Perubahan Output & \multirow{2}{*}{$\begin{array}{c}\text { Pertumbuhan } \\
(\%)\end{array}$} \\
\hline & & (Triliun Rupiah) & & \\
\hline 28 & $1.091,58$ & $1.129,56$ & 37,97 & $3,48 \%$ \\
\hline 29 & 438,37 & 451,16 & 12,79 & $2,92 \%$ \\
\hline 30 & 624,30 & 647,31 & 23,01 & $3,69 \%$ \\
\hline 31 & 116,82 & 126,69 & 9,87 & $8,45 \%$ \\
\hline 32 & 428,95 & 444,53 & 15,58 & $3,63 \%$ \\
\hline 33 & $1.384,44$ & $1.407,21$ & 22,77 & $1,64 \%$ \\
\hline 34 & 190,53 & 213,64 & 23,11 & $12,13 \%$ \\
\hline 35 & $2.245,56$ & $2.315,47$ & 69,91 & $3,11 \%$ \\
\hline 36 & 654,70 & 667,47 & 12,77 & $1,95 \%$ \\
\hline 37 & 390,80 & 415,78 & 24,98 & $6,39 \%$ \\
\hline 38 & $3.395,65$ & $3.529,48$ & 133,83 & $3,94 \%$ \\
\hline 39 & $2.864,69$ & $2.961,56$ & 96,87 & $3,38 \%$ \\
\hline 40 & 330,54 & 319,03 & $-11,51$ & $-3,48 \%$ \\
\hline 41 & $2.463,96$ & $2.805,62$ & 341,65 & $13,87 \%$ \\
\hline 42 & $3.074,87$ & $3.181,66$ & 106,79 & $3,47 \%$ \\
\hline 43 & 588,12 & 609,96 & 21,84 & $3,71 \%$ \\
\hline 44 & 98,41 & 100,45 & 2,04 & $2,07 \%$ \\
\hline 45 & $1.440,64$ & $1.412,70$ & $-27,94$ & $-1,94 \%$ \\
\hline 47 & 548,73 & 568,91 & 20,18 & $3,68 \%$ \\
\hline 48 & 633,27 & 660,06 & 26,79 & $4,23 \%$ \\
\hline 49 & $1.004,34$ & $1.035,36$ & 31,03 & $3,09 \%$ \\
\hline 50 & 297,09 & 304,95 & 7,87 & $2,65 \%$ \\
\hline Total & $24.306,36$ & $25.308,56$ & $1.002,21$ & $4,12 \%$ \\
\hline
\end{tabular}

Sumber: Tabel SNSE Indonesia 2008, diolah

\footnotetext{
${ }^{6}$ Skenario yang dilakukan adalah dengan mengakumulasi dampak pengurangan belanja subsidi BBM terhadap output sektor produksi $(-1,37 \%)$ dengan peningkatan belanja infrastruktur skenario 1 terhadap output sektor produksi $(5,50 \%)$.
} 
Tabel 2. Dampak Injeksi Realokasi Anggaran Belanja Subsidi BBM untuk Pembangunan Infrastruktur (Skenario 2) terhadap Output Sektor Produksi di Indonesia ${ }^{7}$

\begin{tabular}{crrrr}
\hline \multirow{2}{*}{ Kode SNSE } & Output Awal & Output Setelah Shock & Perubahan Output & Pertumbuhan \\
\cline { 2 - 3 } (Triliun Rupiah) & \multicolumn{2}{c}{ (\%) } \\
\hline 28 & $1.091,58$ & $1.170,95$ & 79,37 & $7,27 \%$ \\
29 & 438,37 & 457,34 & 18,97 & $4,33 \%$ \\
30 & 624,30 & 667,58 & 43,28 & $6,93 \%$ \\
31 & 116,82 & 118,76 & 1,95 & $1,67 \%$ \\
32 & 428,95 & 455,63 & 26,68 & $6,22 \%$ \\
33 & $1.384,44$ & $1.401,69$ & 17,25 & $1,25 \%$ \\
34 & 190,53 & 192,68 & 2,15 & $1,13 \%$ \\
35 & $2.245,56$ & $2.370,68$ & 125,12 & $5,57 \%$ \\
36 & 654,70 & 673,77 & 19,07 & $2,91 \%$ \\
37 & 390,80 & 397,51 & 6,72 & $1,72 \%$ \\
38 & $3.395,65$ & $3.480,10$ & 84,46 & $2,49 \%$ \\
39 & $2.864,69$ & $2.941,07$ & 76,39 & $2,67 \%$ \\
40 & 330,54 & 321,52 & $-9,02$ & $-2,73 \%$ \\
41 & $2.463,96$ & $2.472,47$ & 8,51 & $0,35 \%$ \\
42 & $3.074,87$ & $3.197,09$ & 122,22 & $3,97 \%$ \\
43 & 588,12 & 619,01 & 30,89 & $5,25 \%$ \\
44 & 98,41 & 101,33 & 2,92 & $2,97 \%$ \\
45 & $1.440,64$ & $1.422,04$ & $-18,60$ & $-1,29 \%$ \\
47 & 548,73 & 571,73 & 23,00 & $4,19 \%$ \\
48 & 633,27 & 660,88 & 27,60 & $4,36 \%$ \\
49 & $\mathbf{1 . 0 0 4 , 3 4}$ & $\mathbf{1 . 3 8 5 , 7 7}$ & 381,43 & $\mathbf{3 7}, 98 \%$ \\
50 & 297,09 & 308,14 & 11,06 & $3,72 \%$ \\
\hline Total & $24.306,36$ & $25.387,74$ & $1.081,39$ & $4,45 \%$ \\
\hline & & &
\end{tabular}

Sumber: Tabel SNSE Indonesia 2008, diolah

${ }^{7}$ Skenario yang dilakukan adalah dengan mengakumulasi dampak pengurangan belanja subsidi BBM terhadap output sektor produksi $(-1,37 \%)$ dengan peningkatan belanja infrastruktur skenario 2 terhadap output sektor produksi $(5,82 \%)$. 
Tabe1 3. Dampak Injeksi Realokasi Anggaran Belanja Subsidi BBM untuk Pembangunan Infrastruktur (Skenario 3) terhadap Output Sektor Produksi di Indonesia ${ }^{8}$

\begin{tabular}{crrrr}
\hline \multirow{2}{*}{ Kode SNSE } & Output Awal & Output Setelah Shock & Perubahan Output & Pertumbuhan \\
\cline { 2 - 3 } (Triliun Rupiah) & \multicolumn{1}{c}{ (\%) } \\
\hline 28 & $1.091,58$ & $1.150,25$ & 58,67 & $5,37 \%$ \\
29 & 438,37 & 454,25 & 15,88 & $3,62 \%$ \\
30 & 624,30 & 657,45 & 33,15 & $5,31 \%$ \\
31 & 116,82 & 122,73 & 5,91 & $5,06 \%$ \\
32 & 428,95 & 450,08 & 21,13 & $4,93 \%$ \\
33 & $1.384,44$ & $1.404,45$ & 20,01 & $1,45 \%$ \\
34 & 190,53 & 203,16 & 12,63 & $6,63 \%$ \\
35 & $2.245,56$ & $2.343,08$ & 97,51 & $4,34 \%$ \\
36 & 654,70 & 670,62 & 15,92 & $2,43 \%$ \\
37 & 390,80 & 406,65 & 15,85 & $4,05 \%$ \\
38 & $3.395,65$ & $3.504,79$ & 109,14 & $3,21 \%$ \\
39 & $2.864,69$ & $2.951,31$ & 86,63 & $3,02 \%$ \\
40 & 330,54 & 320,27 & $-10,26$ & $-3,11 \%$ \\
41 & $2.463,96$ & $2.639,05$ & 175,08 & $7,11 \%$ \\
42 & $3.074,87$ & $3.189,37$ & 114,50 & $3,72 \%$ \\
43 & 588,12 & 614,48 & 26,36 & $4,48 \%$ \\
44 & 98,41 & 100,89 & 2,48 & $2,52 \%$ \\
45 & $1.440,64$ & $1.417,37$ & $-23,27$ & $-1,62 \%$ \\
47 & 548,73 & 570,32 & 21,59 & $3,93 \%$ \\
48 & 633,27 & 660,47 & 27,19 & $4,29 \%$ \\
49 & $\mathbf{1 . 0 0 4 , 3 4}$ & $\mathbf{1 . 2 1 0 , 5 7}$ & $\mathbf{2 0 6}, 23$ & $\mathbf{2 0 , 5 3 \%}$ \\
50 & 297,09 & 306,55 & 9,46 & $3,18 \%$ \\
\hline Total & $24.306,36$ & $25.348,15$ & $1.041,80$ & $4,29 \%$ \\
\hline & & &
\end{tabular}

Sumber: Tabel SNSE Indonesia 2008, diolah

${ }^{8}$ Skenario yang dilakukan adalah dengan mengakumulasi dampak pengurangan belanja subsidi BBM terhadap output sektor produksi $(-1,37 \%)$ dengan peningkatan belanja infrastruktur skenario 3 terhadap output sektor produksi $(5,66 \%)$. 
Tabel 4. Dampak Injeksi Realokasi Anggaran Belanja Subsidi BBM untuk Pembangunan Infrastruktur (Skenario 4) terhadap Output Sektor Produksi di Indonesia ${ }^{9}$

\begin{tabular}{crrrr}
\hline \multirow{2}{*}{ Kode SNSE } & Output Awal & Output Setelah Shock & Perubahan Output & Pertumbuhan \\
\cline { 2 - 3 } (Triliun Rupiah) & \multicolumn{2}{c}{ (\%) } \\
\hline 28 & $1.091,58$ & $1.138,39$ & 46,80 & $4,29 \%$ \\
29 & 438,37 & 452,48 & 14,11 & $3,22 \%$ \\
30 & 624,30 & 651,64 & 27,34 & $4,38 \%$ \\
31 & 116,82 & 125,00 & 8,18 & $7,00 \%$ \\
32 & 428,95 & 446,90 & 17,95 & $4,18 \%$ \\
33 & $1.384,44$ & $1.406,03$ & 21,59 & $1,56 \%$ \\
34 & 190,53 & 209,17 & 18,64 & $9,78 \%$ \\
35 & $2.245,56$ & $2.327,25$ & 81,68 & $3,64 \%$ \\
36 & 654,70 & 668,81 & 14,12 & $2,16 \%$ \\
37 & 390,80 & 411,88 & 21,08 & $5,39 \%$ \\
38 & $3.395,65$ & $3.518,95$ & 123,30 & $3,63 \%$ \\
39 & $2.864,69$ & $2.957,19$ & 92,50 & $3,23 \%$ \\
40 & 330,54 & 319,56 & $-10,98$ & $-3,32 \%$ \\
41 & $2.463,96$ & $2.734,56$ & 270,59 & $10,98 \%$ \\
42 & $3.074,87$ & $3.184,95$ & 110,08 & $3,58 \%$ \\
43 & 588,12 & 611,89 & 23,77 & $4,04 \%$ \\
44 & 98,41 & 100,64 & 2,23 & $2,26 \%$ \\
45 & $1.440,64$ & $1.414,69$ & $-25,95$ & $-1,80 \%$ \\
47 & 548,73 & 569,51 & 20,78 & $3,79 \%$ \\
48 & 633,27 & 660,23 & 26,96 & $4,26 \%$ \\
49 & $1.004,34$ & $1.110,10$ & 105,77 & $10,53 \%$ \\
50 & 297,09 & 305,63 & 8,55 & $2,88 \%$ \\
\hline Total & $24.306,36$ & $25.325,45$ & $1.019,10$ & $4,19 \%$ \\
\hline & & &
\end{tabular}

Sumber: Tabel SNSE Indonesia 2008, diolah

${ }^{9}$ Skenario yang dilakukan adalah dengan mengakumulasi dampak pengurangan belanja subsidi BBM terhadap output sektor produksi $(-1,37 \%)$ dengan peningkatan belanja infrastruktur skenario 4 terhadap output sektor produksi $(5,57 \%)$. 
Tabel 5. Dampak Injeksi Realokasi Anggaran Belanja Subsidi BBM untuk Pembangunan Infrastruktur (Skenario 1) terhadap Pendapatan Rumah Tangga di Indonesia ${ }^{10}$

\begin{tabular}{crrrr}
\hline \multirow{2}{*}{ Kode SNSE } & \multicolumn{1}{c}{$\begin{array}{c}\text { Pendapatan } \\
\text { Awal }\end{array}$} & $\begin{array}{c}\text { Pendapatan } \\
\text { Setelah Shock }\end{array}$ & Perubahan & \multirow{2}{*}{\begin{tabular}{c} 
Pertumbuhan \\
\cline { 2 - 3 } (Triliun rupiah)
\end{tabular}} \\
\hline 18 & 176,76 & 182,90 & 6,14 & (\%) \\
\hline 19 & 731,56 & 757,96 & 26,40 & $3,47 \%$ \\
20 & 494,23 & 515,74 & 21,51 & $4,35 \%$ \\
21 & 173,15 & 179,87 & 6,72 & $3,88 \%$ \\
22 & 468,45 & 485,72 & 17,27 & $3,69 \%$ \\
23 & 710,50 & 738,31 & 27,81 & $3,91 \%$ \\
24 & 243,91 & 253,07 & 9,16 & $3,76 \%$ \\
25 & $\mathbf{8 2 7 , 8 8}$ & $\mathbf{8 5 6 , 9 6}$ & $\mathbf{2 9 , 0 8}$ & $\mathbf{3 , 5 1 \%}$ \\
\hline Total & 3826,44 & 3970,52 & 144,08 & $3,77 \%$ \\
\hline
\end{tabular}

Sumber: Tabel SNSE Indonesia 2008, diolah

Tabel 6. Dampak Injeksi Realokasi Anggaran Belanja Subsidi BBM untuk Pembangunan Infrastruktur (Skenario 2) terhadap Pendapatan Rumah Tangga di Indonesia ${ }^{11}$

\begin{tabular}{crrrr}
\hline \multirow{2}{*}{ Kode SNSE } & \multicolumn{1}{c}{$\begin{array}{c}\text { Pendapatan } \\
\text { Awal }\end{array}$} & $\begin{array}{c}\text { Pendapatan } \\
\text { Setelah Shock }\end{array}$ & Perubahan & \multirow{2}{*}{$\begin{array}{c}\text { Pertumbuhan } \\
\text { (Triliun rupiah) }\end{array}$} \\
\cline { 2 - 3 } & \multicolumn{3}{c}{ (\%) } \\
\hline 18 & 176,76 & 185,64 & 8,88 & $5,03 \%$ \\
19 & 731,56 & 772,56 & 41,00 & $5,60 \%$ \\
20 & 494,23 & 514,59 & 20,36 & $4,12 \%$ \\
21 & 173,15 & 182,79 & 9,64 & $5,57 \%$ \\
22 & 468,45 & 504,44 & 35,98 & $7,68 \%$ \\
23 & 710,50 & 742,37 & 31,88 & $4,49 \%$ \\
24 & 243,91 & 257,53 & 13,62 & $5,59 \%$ \\
25 & $\mathbf{8 2 7 , 8 8}$ & $\mathbf{8 9 5 , 8 1}$ & $\mathbf{6 7 , 9 2}$ & $\mathbf{8 , 2 0 \%}$ \\
\hline Total & 3826,44 & 4055,72 & 229,28 & $5,99 \%$ \\
\hline
\end{tabular}

Sumber: Tabel SNSE Indonesia 2008, diolah

\footnotetext{
${ }^{10}$ Skenario yang dilakukan adalah dengan mengakumulasi dampak pengurangan belanja subsidi BBM terhadap pendapatan rumah tangga $(-1,40 \%)$ dengan peningkatan belanja infrastruktur skenario 1 terhadap pendapatan rumah tangga $(5,16 \%)$.

${ }^{11}$ Skenario yang dilakukan adalah dengan mengakumulasi dampak pengurangan belanja subsidi BBM terhadap pendapatan rumah tangga $(-1,40 \%)$ dengan peningkatan belanja infrastruktur skenario 2 terhadap pendapatan rumah tangga $(7,39 \%)$.
} 
Tabel 7. Dampak Injeksi Realokasi Anggaran Belanja Subsidi BBM untuk Pembangunan Infrastruktur (Skenario 3) terhadap Pendapatan Rumah Tangga di Indonesia ${ }^{12}$

\begin{tabular}{|c|c|c|c|c|}
\hline \multirow[t]{2}{*}{ Kode SNSE } & $\begin{array}{c}\text { Pendapatan } \\
\text { Awal }\end{array}$ & $\begin{array}{c}\text { Pendapatan Setelah } \\
\text { Shock }\end{array}$ & Perubahan & \multirow{2}{*}{$\begin{array}{c}\text { Pertumbuhan } \\
\text { (\%) }\end{array}$} \\
\hline & \multicolumn{3}{|c|}{ (Triliun rupiah) } & \\
\hline 18 & 176,76 & 184,27 & 7,51 & $4,25 \%$ \\
\hline 19 & 731,56 & 765,26 & 33,70 & $4,61 \%$ \\
\hline 20 & 494,23 & 515,17 & 20,93 & $4,24 \%$ \\
\hline 21 & 173,15 & 181,33 & 8,18 & $4,72 \%$ \\
\hline 22 & 468,45 & 495,08 & 26,62 & $5,68 \%$ \\
\hline 23 & 710,50 & 740,34 & 29,84 & $4,20 \%$ \\
\hline 24 & 243,91 & 255,30 & 11,39 & $4,67 \%$ \\
\hline 25 & 827,88 & 876,38 & 48,50 & $5,86 \%$ \\
\hline Total & 3826,44 & 4013,12 & 186,68 & $4,88 \%$ \\
\hline
\end{tabular}

Sumber: Tabel SNSE Indonesia 2008, diolah

Tabel 8. Dampak Injeksi Realokasi Anggaran Belanja Subsidi BBM untuk Pembangunan Infrastruktur (Skenario 4) terhadap Pendapatan Rumah Tangga di Indonesia ${ }^{13}$

\begin{tabular}{|c|c|c|c|c|}
\hline \multirow[t]{2}{*}{ Kode SNSE } & $\begin{array}{c}\text { Pendapatan } \\
\text { Awal }\end{array}$ & $\begin{array}{c}\text { Pendapatan Setelah } \\
\text { Shock }\end{array}$ & Perubahan & \multirow{2}{*}{$\begin{array}{c}\text { Pertumbuhan } \\
\text { (\%) }\end{array}$} \\
\hline & \multicolumn{3}{|c|}{ (Triliun rupiah) } & \\
\hline 18 & 176,76 & 183,48 & 6,73 & $3,80 \%$ \\
\hline 19 & 731,56 & 761,07 & 29,51 & $4,03 \%$ \\
\hline 20 & 494,23 & 515,50 & 21,26 & $4,30 \%$ \\
\hline 21 & 173,15 & 180,49 & 7,34 & $4,24 \%$ \\
\hline 22 & 468,45 & 489,71 & 21,26 & $4,54 \%$ \\
\hline 23 & 710,50 & 739,18 & 28,68 & $4,04 \%$ \\
\hline 24 & 243,91 & 254,02 & 10,11 & $4,15 \%$ \\
\hline 25 & 827,88 & 865,25 & 37,36 & $4,51 \%$ \\
\hline Total & 3826,44 & 3988,70 & 162,25 & $4,24 \%$ \\
\hline
\end{tabular}

Sumber: Tabel SNSE Indonesia 2008, diolah

\footnotetext{
${ }^{12}$ Skenario yang dilakukan adalah dengan mengakumulasi dampak pengurangan belanja subsidi BBM terhadap pendapatan rumah tangga $(-1,40 \%)$ dengan peningkatan belanja infrastruktur skenario 1 terhadap pendapatan rumah tangga $(6,28 \%)$.

${ }^{13}$ Skenario yang dilakukan adalah dengan mengakumulasi dampak pengurangan belanja subsidi BBM terhadap pendapatan rumah tangga $(-1,40 \%)$ dengan peningkatan belanja infrastruktur skenario 2 terhadap pendapatan rumah tangga $(5,64 \%)$.
} 
Lampiran 3

Tabel 9. Jumlah Rumah Tangga Miskin dan Persentase Rumah Tangga Miskin (Head Count Index) untuk Tiap Golongan Rumah Tangga Antara Sebelum dan Setelah Shock

\begin{tabular}{|c|c|c|c|c|c|c|c|c|c|}
\hline \multirow{2}{*}{ Keterangan Rumah Tangga } & \multicolumn{8}{|c|}{ Kode SNSE } & \multirow{2}{*}{ Total } \\
\hline & 18 & 19 & 20 & 21 & 22 & 23 & 24 & 25 & \\
\hline Total Rumah Tangga & 27260 & 85717 & 25633 & 8415 & 31398 & 27622 & 11454 & 66564 & 284063 \\
\hline Jumlah Rumah Tangga Miskin & 8367 & 29129 & 10512 & 1744 & 0 & 11883 & 1291 & 0 & 62926 \\
\hline Sebelum Shock & $(30,69 \%)$ & $(33,98 \%)$ & $(41,01 \%)$ & $(20,72 \%)$ & $(0,00 \%)$ & $(43,02 \%)$ & $(11,27 \%)$ & $(0,00 \%)$ & $(22,15 \%)$ \\
\hline Jumlah Rumah Tangga Miskin & 8268 & 28757 & 10010 & 1698 & 0 & 11408 & 1266 & 0 & 61407 \\
\hline Skenario 1 & $(30,33 \%)$ & $(33,55 \%)$ & $(39,05 \%)$ & $(20,18 \%)$ & $(0,00 \%)$ & $(41,30 \%)$ & $(11,05 \%)$ & $(0,00 \%)$ & $(21,62 \%)$ \\
\hline Jumlah Rumah Tangga Miskin & 7959 & 27486 & 10078 & 1618 & 0 & 11180 & 1202 & 0 & 59523 \\
\hline Skenario 2 & $(29,20 \%)$ & $(32,07 \%)$ & $(39,32 \%)$ & $(19,23 \%)$ & $(0,00 \%)$ & $(40,47 \%)$ & $(10,49 \%)$ & $(0,00 \%)$ & $(20,95 \%)$ \\
\hline Jumlah Rumah Tangga Miskin & 8112 & 28121 & 10054 & 1657 & 0 & 11291 & 1233 & 0 & 60468 \\
\hline Skenario 3 & $(29,76 \%)$ & $(32,81 \%)$ & $(39,22 \%)$ & $(19,69 \%)$ & $(0,00 \%)$ & $(40,88 \%)$ & $(10,76 \%)$ & $(0,00 \%)$ & $(21,29 \%)$ \\
\hline Jumlah Rumah Tangga Miskin & 8197 & 28523 & 10034 & 1675 & 0 & 11360 & 1251 & 0 & 61040 \\
\hline Skenario 4 & $(30,07 \%)$ & $(33,28 \%)$ & $(39,14 \%)$ & $(19,90 \%)$ & $(0,00 \%)$ & $(41,13 \%)$ & $(10,92 \%)$ & $(0,00 \%)$ & $(21,49 \%)$ \\
\hline
\end{tabular}


Tabel 10. Persentase Rumah Tangga Miskin ( $\left.\mathrm{P}_{0}\right)$, Indeks Kedalaman Kemiskinan $\left(\mathrm{P}_{1}\right)$, dan Indeks Keparahan Kemiskinan $\left(\mathrm{P}_{2}\right)$ untuk Tiap Golongan Rumah Tangga Antara Sebelum dan Setelah Shock

\begin{tabular}{cccrrrr}
\hline \multirow{2}{*}{$\begin{array}{c}\text { Kode } \\
\text { SNSE }\end{array}$} & Ukuran & Indeks Sebelum & \multicolumn{4}{c}{ Indeks Setelah Shock } \\
\cline { 4 - 7 } & Kemiskinan & Shock & Skenario 1 & Skenario 2 & Skenario 3 & Skenario 4 \\
\hline \multirow{2}{*}{18} & $\mathrm{P}_{0}$ & 0,307 & 0,283 & 0,272 & 0,278 & 0,281 \\
& $\mathrm{P}_{1}$ & 0,067 & 0,059 & 0,056 & 0,057 & 0,058 \\
& $\mathrm{P}_{2}$ & 0,021 & 0,018 & 0,017 & 0,017 & 0,018 \\
\hline \multirow{3}{*}{19} & $\mathrm{P}_{0}$ & 0,340 & 0,313 & 0,298 & 0,305 & 0,310 \\
& $\mathrm{P}_{1}$ & 0,078 & 0,069 & 0,064 & 0,067 & 0,068 \\
& $\mathrm{P}_{2}$ & 0,026 & 0,022 & 0,020 & 0,021 & 0,022 \\
\hline \multirow{3}{*}{20} & $\mathrm{P}_{0}$ & 0,410 & 0,357 & 0,360 & 0,359 & 0,358 \\
& $\mathrm{P}_{1}$ & 0,081 & 0,068 & 0,068 & 0,068 & 0,068 \\
& $\mathrm{P}_{2}$ & 0,024 & 0,019 & 0,019 & 0,019 & 0,019 \\
\hline \multirow{2}{*}{21} & $\mathrm{P}_{0}$ & 0,207 & 0,187 & 0,179 & 0,183 & 0,185 \\
& $\mathrm{P}_{1}$ & 0,046 & 0,040 & 0,038 & 0,039 & 0,040 \\
& $\mathrm{P}_{2}$ & 0,015 & 0,012 & 0,011 & 0,012 & 0,012 \\
\hline \multirow{2}{*}{23} & $\mathrm{P}_{0}$ & 0,430 & 0,377 & 0,370 & 0,374 & 0,376 \\
& $\mathrm{P}_{1}$ & 0,079 & 0,066 & 0,064 & 0,065 & 0,066 \\
& $\mathrm{P}_{2}$ & 0,022 & 0,018 & 0,017 & 0,018 & 0,018 \\
\hline \multirow{2}{*}{24} & $\mathrm{P}_{0}$ & 0,113 & 0,102 & 0,096 & 0,098 & 0,100 \\
& $\mathrm{P}_{1}$ & 0,023 & 0,019 & 0,018 & 0,019 & 0,019 \\
& $\mathrm{P}_{2}$ & 0,007 & 0,006 & 0,005 & 0,005 & 0,005 \\
\hline
\end{tabular}

Sumber: SNSE Indonesia 2008 dan Susenas 2013, diolah 
Tabel 11. Penurunan Nilai $P_{0}, P_{1}$, dan $P_{2}$ untuk Tiap Golongan Rumah Tangga Setelah Shock

\begin{tabular}{cccrrrr}
\hline \multirow{2}{*}{$\begin{array}{c}\text { Kode } \\
\text { SNSE }\end{array}$} & Ukuran & Indeks Sebelum & \multicolumn{4}{c}{ Penurunan Setelah Shock } \\
\cline { 4 - 7 } Kemiskinan & Shock & Skenario 1 & Skenario 2 & Skenario 3 & Skenario 4 \\
\hline \multirow{2}{*}{18} & $\mathrm{P}_{0}$ & 0,307 & 0,0240 & 0,0346 & 0,0288 & 0,0262 \\
& $\mathrm{P}_{1}$ & 0,067 & 0,0079 & 0,0112 & 0,0096 & 0,0086 \\
& $\mathrm{P}_{2}$ & 0,021 & 0,0030 & 0,0042 & 0,0036 & 0,0032 \\
\hline \multirow{3}{*}{19} & $\mathrm{P}_{0}$ & 0,340 & 0,0272 & 0,0421 & 0,0346 & 0,0303 \\
& $\mathrm{P}_{1}$ & 0,078 & 0,0090 & 0,0135 & 0,0113 & 0,0100 \\
& $\mathrm{P}_{2}$ & 0,026 & 0,0035 & 0,0052 & 0,0044 & 0,0039 \\
\hline \multirow{2}{*}{20} & $\mathrm{P}_{0}$ & 0,410 & 0,0529 & 0,0500 & 0,0515 & 0,0522 \\
& $\mathrm{P}_{1}$ & 0,081 & 0,0132 & 0,0126 & 0,0129 & 0,0131 \\
& $\mathrm{P}_{2}$ & 0,024 & 0,0045 & 0,0043 & 0,0044 & 0,0044 \\
\hline \multirow{2}{*}{21} & $\mathrm{P}_{0}$ & 0,207 & 0,0198 & 0,0279 & 0,0247 & 0,0225 \\
& $\mathrm{P}_{1}$ & 0,046 & 0,0058 & 0,0082 & 0,0070 & 0,0063 \\
& $\mathrm{P}_{2}$ & 0,015 & 0,0023 & 0,0031 & 0,0027 & 0,0024 \\
\hline \multirow{2}{*}{23} & $\mathrm{P}_{0}$ & 0,430 & 0,0527 & 0,0605 & 0,0567 & 0,0544 \\
& $\mathrm{P}_{1}$ & 0,079 & 0,0127 & 0,0144 & 0,0135 & 0,0131 \\
& $\mathrm{P}_{2}$ & 0,022 & 0,0040 & 0,0046 & 0,0043 & 0,0042 \\
\hline \multirow{2}{*}{24} & $\mathrm{P}_{0}$ & 0,113 & 0,0111 & 0,0165 & 0,0145 & 0,0126 \\
& $\mathrm{P}_{1}$ & 0,023 & 0,0032 & 0,0046 & 0,0039 & 0,0035 \\
& $\mathrm{P}_{2}$ & 0,007 & 0,0011 & 0,0016 & 0,0013 & 0,0012 \\
\hline
\end{tabular}

Sumber: SNSE Indonesia 2008 dan Susenas 2013, diolah 